\title{
The Contribution Professional Codes of Conducts on Secondary Education Teacher's Professionalism: A Case of Bukoba District Council, Kagera Region, Tanzania
}

\author{
Julius Justus Rweyemamu, Joseph M. Kamugisha
}

Department of Education Foundation, St. Augustine University of Tanzania, Tanzania

Email: rweyendelajulius@gmail.com

Received: 06 Dec 2021; Received in revised form: 22 Jan 2022; Accepted: 02 Feb 2022

(C)2022 The Author(s). Published by TheShillonga. This is an open access article under the CC BY license

(https://creativecommons.org/licenses/by/4.0/)

\begin{abstract}
The main purpose of this study was to examine The Contribution of professional codes of conducts on secondary education teacher's professionalism: A Case of Bukoba District Council, Kagera Region, Tanzania. The study was guided by deontological and utilitarianism theories. The research employed a mixed research approach under convergent parallel research design. The study used a population of 238 with the sample size of 149 comprising of 1 DSEO, 13 WEOs, 13 Head of Schools, and 122 Teachers. The sample was obtained by simple random sampling and purposive sampling technique, and data were gathered by using questionnaires and interview guide. What's more, cronbach alpha coefficient approach was used to ensure the reliability of the instruments. Obtained finding were analyzed using Statistical Package for Social Sciences (SPSS) version 20 computer package. Data was analyzed by using descriptive statistics and the findings were presented by using frequency tables and pie-charts. Also, part of qualitative data wascodedand categorized by thematic analysis of which description were employed to present data in chapter four. The findings indicated that in teaching professionalism there is ethical and moral practice, moral development and moral values which are caused professional codes of conducts to teachers.In addition, it was found that professional codes of conducts raise the standards of teaching professionalism, brings about respect, integrity and obedience to laws. The study recommended that the government and other educational authorities to put more emphasize on the moral development to teachers because it is one of the important that contribute to ethical practice.
\end{abstract}

Keywords - Contribution, Professional codes of Conducts, Teachers education, Professional ethics, Secondary education and Teacher's professionalism

\section{INTRODUCTION AND BACKGROUND}

Professional teacher are the key implementers of school curriculum, therefore we cannot lag their ethical behind in their daily act and practice. Professional teachers need a conceptual and practical link through, professional codes of conducts.The process of teaching needs ethical competences and moral values in evaluating ethical dilemmas and behavioural dispositions in education. Also many countries worldwide had programs of educating their teachers in moral aspects believing that teachers are in charge of handling students in moral dimensions. Any profession needs standard and codes to guide action for the proper practice and effective performance. Quality education cannot be there without an effective teacher who is able to abide ethical principles that facilitate effective teaching and learning process at school. Teachers who are provided with professional codes of conducts are able to set objectives in relation to curriculum requirements, Variety of teachers are not aware on the contribution of professional codes of conducts in their profession although they have shadow understanding the principle. This issue of ethical practice in most professionals is concurring heads of many researchers. Professional conducts are the need in each career; it ought to be taken under consideration in using people and in painting surroundings. Considering that schooling has a decisive effect on the improvement of the society and the country at large, this is why many countries are required to take professional ethics into consideration in relation to coaching practices.The element of teacher schooling began to recede into the background as teacher training became delivered below the auspices of the college through the centresince $18^{\text {th }}$ century (Labaree, 2008). 
During s1980s, discourses in teacher education seemed to converge, making it clean to many who renewed prioritization of the ethical and moral dimensions of teaching in teacher training to turn into pressing, if not a foregone conclusion. Nash (2002) explains that three moral languages, rules and standards, individual and primary ideals endure moral troubles and expert ethics. Professional ethics within the history of training aimed to put together instructors with right moral behaviour and students with moral practices.

Boon (2013) explains that ethical practice is still the problem to many professionals in different countries and these results to the needs of rising the knowledge of ethics and professional codes of conducts. Boon adds more by saying that most of European countries are putting more efforts on mandating the courses of professional ethics in teaching professionalism in order to prepare graduates who are moral and ethical competent. In connection to this, professional codes of conducts has great contribution on professionalism that why most of countries are seeking to put more emphasis on teaching professionalism. Numerous excessive-profile educationalists explain that the primary theory of professional ethics expertise that had emerged with the modernization of medical training specializing in familiarizing college students with codes of ethics; the ethical standards embedded in practice, the inherent ethical complexity of professional's paintings (and the attendant ethical dilemmas) now has an area in trainer training. In German most of institutions and programs were set in sense of keeping graduates aware of the codes of practices that guides their professions, this also included the programs of teaching professional teachers and other reactionaries the roles of ethics in professionalism.

Walther, (2013) insists that Most of UK and US nations such as Canada, Australia and Germany has put more emphasis in ethical practice to professionals, this was to show the contribution of professional codes of conducts in teaching education. Students cannot be moral competent if their teachers are not ethically guides in their profession, this is done by the initiation of guideline and principles that guides teachers behaviors and daily obligations in teaching activities.With respect to the discourse on the professionalization of teachers and teachings, anumber of scholars take as a key premise in the argument that ITE should include theexplicit teaching of ethics content that knowledge of the profession's ethical norms is a basicrequirement of professionalism and professional practice (Campbell,2011, 2013; Soltis, 1986; Strike, 1990; Watras, 1986). This shows more emphases more on the contribution of professional codes of conducts in teaching professionalism. Different teachers in their schools does not mean that are not aware of the professional codes of conduct, but sometimes do not understand the contribution of these professional codes of ethics which sometimes results in ethical dilemmas when solving their obligations.

Campbell (2008, 2011, 2013); and Boon, (2011) at the importance of ethics on teachers, each argues that there may be a want to better recognize how ethics curriculum and content are handled in trainer education. In United State of America, in the Kindergarten level of education, 12 teachers are directed to own the understanding of ethics as the contribution of preparing students who are not simplest pedagogically competent, however additionally informed in moral exercise and moral compass.

Australia and other international locations in the world enforced different programs that contribute on the significance of ethics knowledge towards teaching professionalism. Boon (2011) found that pre-service teachers in secondary education felt a need for training in ethics that was not being adequately met by their program. Australia Institute for Teaching and School Learning (AITSL) mandated the training of teachers who were disposition and put it as among the qualification for the accreditation of the teaching professionalism. Further, in Australia, pre-service teachers (PST), in order to graduate from accredited program, one must possess some attributes of ethics which must be demonstrated to the classroom and to the community. AITSL (2011) shows that beyond graduation, in the classroom, professional teachers must behave professionally and ethically in all forums, and finally highly accomplished teachers must behave ethically at all times. Professional ethics knowledge contributed significantly to teachers on improving moral dispositions in Australia and improved moral and ethical practices such as; respect to students, safety and health of students, confidentiality and privacy, trust and law obedience. Australia Institute of Teaching and School Learning (AITSL) mandated the training of teachers to include ethics and make it among the qualification for the accreditation of the teaching professionalism (AITSL, 2011).

In Canada, different feminist's scholars introduced ethics of cares and ethics of others in order to make people and other professionals aware on the contribution of ethics in the societies. Education system plays a very crucial role in any country towards achieving sustainable development and quality education (Little \& Rolleston, 2011). Given the due recognition of the significance of the education system, countries practice and promote fee free education policy as the contribution of recognising rights of every child to get education; this is one among of ethics that insists on respecting of others and human right.

Kertayeva (2013) asserts that in Botswana, lack of adherence to professional ethics and professional codes of 
conducts as a violation to ethical requirement in teaching profession. It is insisted that this cause negative effect on students learning. Jacques goes far by saying a teacher may be competent in pedagogical content and in teaching, and students may have good performances but if they lack ethical contents, the class can be overcrowded with immoral actions and unethical behaviours

The study conducted by Gobagoba and Moswela(2014), on ethics education adherence by teacher trainees during teaching practice on Botswana perspective found that most of professional teachers especially male teachers involve in sexuality with female students. The results revealed that such behaviours are initiated by absence of enacted professional codes of conducts and ethics that teachers can relate with their practices. Gobagoba and Moswela insist in their conclusion that professional codes of conducts to teachers are vital to increase and raise the image of teaching profession in Botswana and to the education training institutions. The recommendations of Gobagoba insisted that ethics education should be mandatory to all institutions in Botswana.

In other countries, teachers are not familiar with what code of ethics demand, though they are practicing them (Anangisye, 2005).

For many years in Tanzania, professional codes of conducts for the Public Service were issued for the first time since our independence in 1961. During the colonial rule, Codes of Ethics and Conduct was inherent in different laws and regulations. It believed that the Code will also enable Public Servants to involve themselves fully in fulfilling the mission of the Public Service, which is to offer quality, effective and efficient service to Tanzanians, while maintaining the highest standard of courtesy and integrity (URT, 2017). The report from the Teachers' Service Department (TSD) for 2008/2009 and 2010/2011 indicates that 472 teachers were fired yearly for professional misconduct in Tanzania (URT, 2011).The government statistics show that 39 primary school teachers were dismissed from teaching profession in 2011 because of misbehaviour and 145 of them because of truancy (BEST, 2012). This number is unusual. Teachers need to operate in accordance with. It seems that in Tanzania, the observance of the codes of conduct by primary school teachers is too low. The available data shows that the Teachers Service Department (TSD) which is accountable with teachers' disciplinary issues related to professional misconduct dismisses 200 to 300 teachers every year for various professional misconducts (TSD, 2008). Various concerns have been raised on the way the TSD deals with indiscipline cases among teachers in Tanzania. There has been much focus on immoral sexual misbehaviour and less focus on those teachers who do not attend classes punctually and who do not help weak learners (Osaki, 2012). Other teachers are very alcoholic and misconduct themselves outside the class and sometimes are cruel to learners but the responsible organs including TSD do not deal with such professional misconducts. When we trace professional teacher's ethics conducts on primary school teachers, we cannot leave secondary education teachers especially in Bukoba District Council behind since it is the Part of Tanzania.

I may end my remark by quoting Aristotle who said, "Educating the mind without educating the heart is no education at all." Similarly, Campbell (2008) argues that ethical conducts enable teachers to make conceptual and practical links between core moral and ethical values such as honesty, compassion, fairness, and respect for others and their own daily choices and actions. Ethics and teaching seem inherently compatible and unavoidably intertwined (Campbell, 2008). Separating professional conducts in teaching profession is the preparation of teachers with no proper codes of conduct with immoral values. This shows that when you become servant personnel, ethics is the core character that you need to possess in order to know what is right in the society and what is wrong in serving.

\subsection{Statement of the Problem}

The problem of ethical practices is widely reported on the African continent and Tanzania in specific (Leach, 2001; Leach, et al, 2003; Anangisye and Barret, 2005; Betweli, 2013; Anangisye, 2011). As such, reports of teachers' unbecoming behaviours have been happening for quite some times now. The most outstanding aspect in these reports of teachers' misconduct cases has to do with their happening in a profession dominantly defined by moral character. In consequence, one wonders whether professional teachers are adequately familiarwith Professional codes of conduct.

More importantly, studies done on the aspect of professional conducts overlooked the contribution of professional codes of conducts for secondary education teacher's professionalism. Such studies go deep on public servant, primary teachers and not specific to secondary education teachers particularly in Bukoba District Council, but generalized Tanzania public servants. Therefore, this motivated the researcher to conduct the study on the contribution of professional codes of conducts to secondary education teacher's professionalism in Bukoba District Council, Kagera Region, Tanzania. Therefore, this study aimed to raisethe awareness and understanding of the contribution of professional codes of conducts in teaching professionalism. Professional codes of conduct is the vital element in any practice in the society and public services, hereafter; the study is significant in providing the 
knowledge and an understanding the contribution of professional codes of conduct in teaching profession, furthermore, the study brings teachers with awareness on the significance of adherence to professional codes of conducts and ethics in teaching process. Finally the findings provide the government and authority with the contribution of professional codes of conducts that will cause to put more emphasis in order to raise the standard of teachers' profession.

\section{THEORETICAL FRAMEWORK}

A theory is an analytical tool for understanding, explaining and making predictions about a given subject matter or a phenomenon. Theoretical framework is constituted by the specific perspective which a given researcher uses to explore, interpret or explain events or behaviour of the subjects or events she/he is studying (Imenda, 2014). There are many theories in education that can ground this research but this study will be grounded by Utility Theory and Deontology Theory. Utilitarianism theory was pioneered by Jeremy Benthan an English philosopher and a Social reformer in $1748-1832$. The theory of utilitarianism states that we should perform those acts which will bring the most happiness. Deontological ethics is an ethical theory spread by Immanuel Kant, (1724-1804) in the 18th-century that place special importance on the relationship between duty and the morality of human actions in everyday life. Deontological theory states that people should adhere to their obligations and duties when analysing an ethical dilemma. The expectation of utility theory and deontology theory are to express the moral actions and codes of conduct through professional practices in this study

Theories explain how people develop specific beliefs that guide their thinking and actions in specific socio-cultural contexts (Kombo and Tromp, 2006). Ethics is generally regarded as being associated with moral conducts of all human actions, behaviour, practice and attitudes that in turn motivates learning behaviour which may cause the attainment of quality education (Maxwell and Schwimmer, 2016). Typically articulated in a professional code of conducts or cognate document, the norms of ethical professionalism are meant to guide practitioners' conduct for a specific social purpose. This study was guided by two theories (Deontological and Utilitarianism theory) due to differences in implication. Deontological theory insists on the significance of adhering to duties and responsibilities in defining ethical practice, while utilitarianism theory insists on doing the good (moral conducts) for the benefit of the utility (the society, community, students and colleagues). Therefore, since these two theories suppress each other to bring the relevance of this study, their use is justified.

\section{METHODOLOGY}

This study used a mixed research approach with convergent parallel design. The target population of this study were 195 public secondary education teachers, 13 schools' heads (HoS), 1 District Secondary Education Officer (DSEO) and 29 Ward Education Officers (WEOs) found in Bukoba District Council. This made a total population of 238. The study employed both probability and non-probability sampling technique in which Purposive sampling was used as a non-probability sampling technique to select heads of schools (HoS), Ward Education Officer (WEO), and District Secondary Education Officer (DSEO). The study involved a sample of 1 DSEO, 13 WEOs $13 \mathrm{HoS}$ and 122 secondary education teachers from the sample frame that made a total sample of 149 . On other hand the employed Cronbach's Alpha approach in determining the reliability of research instruments. Data were collected by the aid of questionnaires and qualitative data was collected by the aid of a sound recorder and note taking. Data was analysed basing on both qualitative and quantitative data analysis methods. Quantitative data which were obtained from questionnaires were analysed by using statistical software called Statistical Package for Social Science (SPSS) version 20. Finally, data analysed by using descriptive statistics like percentages and frequencies were presented in form of pie charts, and tables. Qualitative data obtained through interview and open ended questionnaires was analysed thematic analysis by highlighting main themes which provided answer for each specific objective.

\section{FINDINGS AND DISCUSSION}

\section{Demographic information of the respondents}

Table 1 Demographic Information of Informants

\begin{tabular}{|l|l|l|l|}
\hline Variable & Category & Frequency & Percentage \\
\hline \multirow{4}{*}{ Gender } & Male & 70 & $57.3 \%$ \\
\cline { 2 - 4 } & Female & 52 & $42.6 \%$ \\
\hline Age in Years & $18-25$ & 0 & $0 \%$ \\
\cline { 2 - 4 } & $26-33$ & 25 & $20.4 \%$ \\
\cline { 2 - 4 } & $34-40$ & 58 & $47.5 \%$ \\
\cline { 2 - 4 } & $41+$ & 39 & $31.9 \%$ \\
\hline \multirow{3}{*}{$\begin{array}{l}\text { Experience in } \\
\text { Years }\end{array}$} & 1 & 2 & $1.6 \%$ \\
\cline { 2 - 4 } & $1-4$ & 18 & $14.7 \%$ \\
\cline { 2 - 4 } & $5-9$ & 30 & $24.5 \%$ \\
\cline { 2 - 4 } & $10+$ & 72 & $59 \%$ \\
\hline
\end{tabular}

Source: Field data, 2021 
Demographic information in this study was collected to show the characteristics of the respondents participated in this finding. The information collected based on gender, age and years of experience of professional teachers. The findings indicate that $47.5 \%$ of teacher's age ranged $34-40$ years, $31.9 \%$ had the age of $41+$ years and the rest $20.4 \%$ ranged between 26-33 years. Also table 1 above indicates

Table 2: The Contribution of Professional Code of Conduct in Teaching Profession

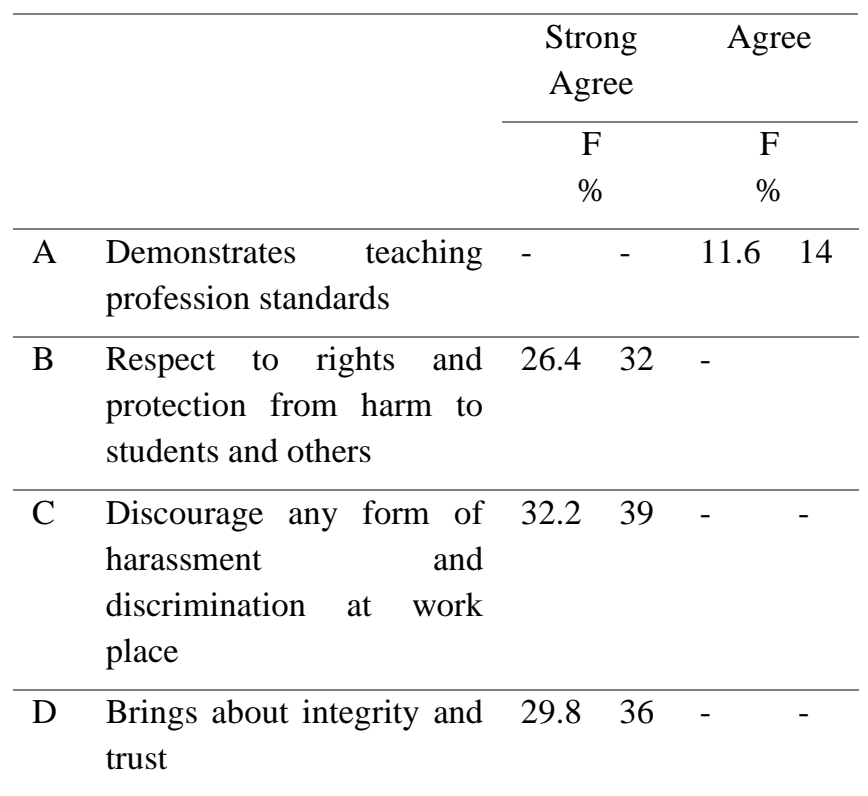

Source; Field Data (2021)

\section{Demonstrate High Standards of Professional Practice}

The table 2above indicate that $14 \%$ of the informants agreed strongly on the contribution of professional codes of conduct to the increase of teaching profession standards. These codes of regulate immoral behaviours and unethical practices. This is to say that most of ethical dilemmas facing teachers in making decisions at the working environment are solved with ethical standards of practices. Most of unethical behaviours such as alcoholism, corruptions, and miss use of power will never have the chance of existence if these codes will be insisted on ethical practice.

Through the interview one W.E.O, commented;

Professional codes of conducts are what cause our profession respectful, and raise the standards of the profession, For Example, the society will judge a teacher as immoral if he/she will be a drunkard, participate in corruption and other unethical behaviour, and this in turn makes the whole profession to be of poor standards if the staffs are under immoral behaviour and vice versa. But these that the $57.3 \%$ of teachers were males and $42.6 \%$ of teachers were females. This indicates that both genders were involved in this study. The findings show that $59 \%$ of teachers have working experience of more than 10 years while $50 \%$ of teachers have less than 10 years of working experience.
professional codes of conducts have made important roles on shaping the image of this profession and raise its standards since teachers are able to respect each other and live with students in a sense that moral growth exists (Interview/WEO, September, 2021).

Therefore, it was found that professional codes of conduct do not contribute only on behavioural change but also brings respect on the professional who in turn increases the standards of teaching profession. Also Head of School A in his comments said:

In order to meet the texture and standard
of any program, profession or life style
you can't avoid principles and rules as we
have codes that guide our profession in
education. These codes are what make
the taste of teaching process to be seemed
as the moral and ethical process in
preparing our students and literate
profession. (Interview/Head of school A,
September 2021)

This finding concurs with DET (2006) that indicates that increases teaching professional standards through providing constructive feedback to colleagues that is considered helpful, assisting in developing and mentoring beginning teachers to work cooperatively and collaboratively with others to achieve school and system goals, informing people of their rights and entitlements where appropriate and accepting responsibility for their own professional learning and development. Thus, professional codes of conduct demonstrate the standards of teaching profession.

According to Benninga (2003) who concludes that teachers play an important role in children's character formation. Teachers provide children with a basic but essential moral education. So, teachers should focus on providing the way and guidance to students to make them well behaved individuals, and inculcate good attitude within them. Therefore, teachers to inculcate the fundamental professional ethics and values within them, they need professional codes and ethical standards which demonstrate teaching profession.

Witty, (2006) sees the purpose of codes of ethics as rising, maintaining and promoting the status of teaching 
profession. These codes of conducts make professional teachers to adhere to responsibilities and not to breach laws, to respect their employers' agreements and to respect others' rights not only in schools but also outside the environment. Many professionals in the field of education are aware of these though an obligation of living them sometimes becomes difficult. Everyone knows that moral acts are important on ones 'behaviours but dilemma raises on making choices on the dos and don'ts. Here is where principles and need to stand in order to make the generalization of teachers practice.

\section{Respect to Rights and Protection from Harm to Students and Others}

The finding in table 2 indicates that $32 \%$ of respondents agreed that contribute to respect of human right, and protection of students from harm. This keeps students safe in school environment and builds good relationship between then and their teachers. Also, staff members protect each other since standards and codes keep promises of respecting each other. Everyone feel free to work effectively and efficiently if he or she is sure of the safety of the surrounding environment.

The Comment from DSEO, says:

We can't say that teaching professional is ethical if students are in danger and cannot be kept in safe environment. If staff members are not protecting each other, teachers and students' rights are not held in safe hands. We can solve all these through these codes of ethics and in teaching profession. (Interview/DSEO, September, 2021).

On the same side through the interview with W.E.O, said that

We act as professionals since we have
rules hat abides us, we live the codes
that insists us to take care of students
and ourselves, to make teaching and
learning environment friendly and to
do the right and avoid the wrong
because these codes of profession
conducts are what make every teacher
abide by ethical practices and moral
obligations in decision making.
(Interview/WEO, September 2021)

The above finding is also consistent with Utilitarianism theory, By Jeremy Bentham (1748-1820) which insists that people should do what do not harm the majority but what makes them happier. From this point of view, professional codes of conducts act as the bare rock of teachers in teaching profession to make proper decision in their daily choices. Furthermore, the society needs to see what makes them happier and these are to respect rights of students, respect their rights in decision making participation and protecting their students from harm and dangerous environment like raping and the use of drugs in school environment and out of schools.

\section{Integrity and Trust}

Trust and integrity are the core values of moral conduct not only to professional teachers but to any public servant. It is easy to work effectively and perform at this standard but if trust and integrity lack at the middle of conducts, judgement will be on ethical practice.The finding above shows that $36 \%$ percent of respondents agree that professional codes of conduct contribute to trusts and integrity to teachers. In this sense, teaching profession cannot be separated from. It is able to teach but not to prepare students with moral character.

Also, in the interview with Head of School C, he said,

Trust and Integrity are what bare moral values; this prevents teachers from behavioural misconduct in schools like examination corruption and obedience to laws. A teacher with no trust or any profession is not able to produce a good outcome of his class. For example, an obedient professional teacher will never breach the codes of professional conduct; will never engage in sex with students and his/her pedagogical competence will be high (Interview/Head of School C September 2021).

Also, this sense concurs with Kertayeva (2013) in his study about moral and ethical issues in teacher education. He comments that code of ethics increases the professionalization of teachers in aspects of moral conducts and commitment to work. Keep teaching process moral and lead to the preparation of students with moral conducts. In Australia the codes namely integrity, respect and responsibility are objected to keep professional teachers, pre service teachers and graduates to live the life of moral acts. It is believed that these set principles are to make the partial link between ethical content and pedagogical competence. Through these findings, it is concluded that keep the trustfulness, integrity and responsibility of professional teachers which make the process of education better in moral compass. 


\section{Discourage any Form of Harassment and Discrimination at Work Place}

For these reasons, then, the researcher joins his voice to that of teachers and heads of schools who argue that professional codes of conducts discourage harassments and discrimination at work place. Any form of harassment and discrimination cannot exist at a work place where there are moral conducts and obedience to professional codes of conducts. The findings above indicate the relevance of the contribution of codes of professional development by $39 \%$

WEO of ward F in his comment, said;

Harassment and discrimination do not
affect only students in classrooms but
also employees (teachers). Any time
that an employer discriminates an
employee in any case either through
corruption, abusive language or
favouritism does not favour better
production of outcomes. Better student
arises from the process built under
strong ethical foundations and
pedagogical competences
(Interview/WEO of ward F, September
2021)

These comments directly ensure the chance of professional codes of conducts to teaching professionals that ethics and professionalism are compatible and intertwined in achieving quality teachers. Also,Maxwell (2017) identifies professional ethical codes as the element of theoretical knowledge. Hence, the build the foundation of moral preparation of students in schools, teachers and educational authorities such as; WEOs and DSEOs. In connection to this, ethical practice raises to the ethical standards of professionals and the system in general. This is to say any position or act that do not harm others, is judged by the utility as the good act, and this is in line with utilitarianism theory which emphasises more on performing acts which produce the good (happiness) to the greatest number.

\section{CONCLUSION AND RECOMMENDATION}

It is undeniable truth that professional codes of conducts are the vital element in shaping professionalism and professional conducts in teaching process. In that sense professional codes of conducts in teaching professionalism found to be of significant since the findings revelled that the standard of teaching profession, are held by teachers practice and professional conducts. On other hand, professional codes of conducts hold moral values and ethical practices. It is the shame to lead and recruit teachers who's their ethical disposition is immoral and expects graduates with ethical competence; this is to say codes of professional conducts are the elements that can note be taken for granted in teaching profession. To put in nutshell, is to say they strengthen ethical and moral practice on teacher's professionalism. The school administration and the government should put more emphasize on the codes of conducts in order to keep professionals practicing this ethical behaviour rather than keeping them with guidelines and documents that are not insisted and taken for granted. Yearly seminars and educational programs to discuss the significance and contributions of professional codes of conducts to teachers in teaching process instead of laying out these codes and wait for teachers to abide by them.In addition, the researcher has discovered that the majority is aware of professional codes of conduct therefore recommends the authority to keep this awareness to professional teachers through intra seminars and training so as to stay up to date.

\section{REFERENCES}

[1] Anangisye, W. A. L. \& Barrett, A. M. (2005). Professional identity and misconduct: perspectives of Tanzanian teachers. Southern African Review of Education with Education with Production,7(11), 5-22.

[2] Anangisye, W. A. L. (2011). Why are teachers motivated to behave unprofessionally? A qualitative-data-based-inquiry on education stakeholders' experiences in Tanzania. LWATI: A Journal of Contemporary Research, 8(1), 1 -23.

[3] Anangisye, W. A. L. (2013). Conceptualizing the professional nature of the teaching enterprise: A critical review. UTAFITI, 10(1), 1 -18.

[4] Australian Institute for Teaching and School leadership (AITSL). (2011). National professional standards for teachers. Melbourne; Brisbane; Canberra: Australian Government. Venereol. Leprol, 70(2), 123-128.

[5] Benninga, J. S. (2003).Moral and ethical issues in teacher education. ERIC Clearing house on Teaching and Teacher Education.

[6] Boon, H. (2011). Raising the bar: Ethics education for quality teachers. Australian Journal of Teacher Education, 36(3), 76-93.

[7] Campbell, E. (2003). The Ethical Teacher, Open University Press.

[8] Campbell, E. (2006). Ethical Knowledge in Teaching: A Moral Imperative. Education Canada, 46(4), 32-35.

[9] Campbell, E. (2008). Preparing ethical professionals as a challenge for teacher education. In K. Tirri (Ed.), Educatingmoral sensibilities in urban schools (pp. 3-18). Rotterdam/Taipei: Sense Publishers.

[10] Campbell, E. (2011). Teacher education as a missed opportunity in teacher education. Rotterdam/Taipei: Sense Publishers.

[11] Campbell, E. (2013). Cultivating Moral and Ethical Professional Practice. In M. Sanger \& R. Osguthorpe (Eds.). The moral work of teaching and teacher education: 
Preparing and Supporting Practitioners (pp. 29-44). New York: Teachers

[12] Gobagoba, Marina; and Moswela B (2014). Ethics education adherence by teacher traineeduring teaching practice; A Botswana perspective. Educational Research andReviews, 9(7), 199-207

[13] Imenda, S. (2014). Is there a conceptual difference between conceptual and theoretical frameworks? Journal of Social Science, 38(2), 185-195.

[14] Kant, I. (1986). The metaphysics of ethics. Edinburgh: T. \& T. Clark George Street.

[15] Kertayeva, G. (2013). Deontological preparedness of a teacher as a guarantee of psychological comfort in theclassroom. Literacy Information and Computer Education Journal (LICEJ), 4(4), 1252-1258.

[16] Kombo, D. K., and Tromp, D. L., (2006). Proposal and thesis writing: An introduction. Nairobi: Paulines Publications Africa.

[17] Labaree, D. (2008). An uneasy relationship: The history of teacher education in the university. In M. Cochran-Smith., S. Feiman-Nemster., \& J. McIntyre (Eds.), Handbook of research and teacher education ( $3^{\text {rd }}$ ed.). (pp. 290-306). Washington, DC:Association of Teacher Educators.

[18] Labaree, D. (2008). An uneasy relationship: The history of teacher education in the university. In M. Cochran-Smith., S. Feiman-Nemster., \& J. McIntyre (Eds.),Handbook of research and teacher education ( $3^{\text {rd }}$ ed.). (pp. 290-306). Washington, DC: Association of Teacher Educators.

[19] Maxwell. B, (2017). Codes of professional conduct and ethics education for future teachers Philosophical Inquiry in Education, 24(4), 323-347

[20] Maxwell. B., \& Schwimmer, M. (2016). Professional ethics education for future teachers:A narrative review of the scholarly writings. Journal of Moral Education, 45(3), 354371.

[21] Nash, R. (2002). Real world ethics: framework for educators and hman services professionals. $2^{\text {nd }}$ Ed. New York: Teachers Colage Press

[22] Teachers Service Derpartment, (2008). Teachers dismissed from Various discipline corruption in Education Sector

[23] United Republic of Tanzania, (2017). National framework for continuous professional development for practicing teachers. ministry of education, science andtechnology.

[24] URT, (2017). Code of ethics and conduct for the public service Tanzania. Tanzania 